\title{
THE INTERESTS OF MAIN STAKEHOLDERS IN THE COMMERCIALISATION PROCESS OF BUSINESS VENTURES WITHIN UNIVERSITY BUSINESS INCUBATORS
}

\begin{abstract}
Summary
The justification and directions of support for business ventures by innovation and entrepreneurship centres are nowadays the subject of extensive scientific and political discourse. The paper aims at adding arguments to this discussion, based on the results of empirical research conducted on the basis of the case study strategy carried out among companies developing in such centres in Poland in comparison with more developed countries, including the UK, Belgium and Ireland. Particular attention is paid to the issue of involvement of key stakeholders at various stages of business development, including universities and their business incubators as well as potential investors providing key resources to this development, combined with general economic objectives the achievement of which justifies public expenditure on support of specific entities. The conducted analysis is based on the process approach in the framework of which characteristic phases of business development are distinguished, since the company's establishment to the point when it gains the potential for global development. The analysis shows first of all that there is no contradiction between objectives of individual stakeholders of the process, provided that they are properly targeted. University business incubators seem to be a good coordinator of these objectives if their activities are carried out in an appropriate manner.
\end{abstract}

Key words: commercialisation process, business ventures, university business incubators, stakeholders

\section{Introduction}

The contemporary literature indicates that one of the most important tools enabling economic use of knowledge, through formal [Agrawal, 2001], as well as informal [Acs et al., 2009; Audretsch, Aldridge, 2009] transfer channels, is entrepreneurship. First of all, it is stressed that innovative entrepreneurship allows to achieve the long-term economic growth. For example, the net employment growth in the USA in the last two decades of the twentieth century caused by the development of new entrepreneurial firms (less than five years old), [OECD, 2010; Janasz, 2004]. The so called technology firms play a special role in this process [Stawasz, 2006], causing an imbalance in the

\footnotetext{
${ }^{1}$ Katarzyna Lobacz, Ph.D. - Department of Effectiveness of Innovation, Faculty of Management and Economics of Services, University of Szczecin, e-mail: katarzyna.lobacz@wzieu.pl. Professor Piotr Niedzielski - Department of Effectiveness of Innovation, Faculty of Management and Economics of Services, University of Szczecin, e-mail: piotr.niedzielski@wzieu.pl.
} 
market [Schumpeter, 1934] through commercialisation of breakthrough technologies [Kozmetzky et al., 2004]. One of the tools designed to stimulate such activities are university business incubators which are intended to form a bridge between universities, where new knowledge is created, and the economy. Business incubators, in particular those associated to universities, are nowadays seen as a key component of regional and national economic development strategies, supporting and strengthening the growth of economic sectors [Harman, Read, 2003]. However, when defining the role and tasks of incubators, the question should be answered: what conditions in functioning of university business incubators must be met in order for this objective (the economic growth and development) to be achieved.

The sense and directions of support for business ventures provided by innovation and entrepreneurship centres are nowadays the subject of extensive scientific and political discourse. Effects of activities carried out by business incubators in general and by university business incubators are not consistent in subsequent reports. On the one hand, it seems that their support determines the survival of a large number of companies and their development, on the other hand, there are examples of negligible impact [Clarysse, Moray, 2004; O'Shea et al., 2005; Rothaermel, Thursby, 2005] or even harmful effects. For example, in the USA reports indicate a 70-80\% survival rate for companies in university incubators and $90 \%$ as the overall average, while the average survival rate of companies in the first four years of activity is less than $50 \%$. Other studies show that the organization of the infrastructure supporting business operations does not meet the needs of university companies and inadequate resources to finance business support services can be a factor that hinders their development [Muent, 1999]. It can be assumed that such different results are derived from diverse quality of the support offered and its appropriateness in relation to the needs of specific companies. This seems all the more likely due to the fact that results derived directly from incubators meeting appropriate quality criteria show positive results according to different measurement indicators [BIC Observatory 2010, 2011]. All these doubts raise a question as to whether services offered by incubators are really important and should be subsidised.

The lack of clarity as to effectiveness of activities carried out by incubators is also connected with difficulties in identifying the essence of this effectiveness [Phan et al., 2005]. Typical indicators used to measure effectiveness of incubation programmes comprise the number of companies created, the number of jobs, the rate of survival of companies and the generated revenue [Campbell, 1989; Lyons, 1990]. In general, however, there is no consensus on success factors related to the support offered by an incubator. Due to the strongly manifested need for a more sophisticated, not necessarily direct, approach to the analysis of effects generated by incubators [Phan et al., 2005], many indicators for their measurement have been suggested over the recent years. In addition to studies encompassing key performance indicators, effectiveness of the use of tangible and intangible resources as well as critical success factors [Smilor, 1987; Allen, McCluskey, 1990; Mian 1994, Mian 1997], there are also benchmarking studies [BIC Observatory 2010, 2011; ASTP benchmarking, in which incubators are assessed in comparison to others with similar profile. At the same time, it is said that results of such benchmarking 
studies cannot be presented in the form of an overall assessment. These analyses, however, neglect the aspect of indirect economic effects that should also have an impact on the decision making concerning subsidising specific support centres.

The above-presented ambiguities justify the need of the proposed research study. The paper aims at adding arguments to the discussion on potential effects generated by university business incubators, based on the analysis of objectives of key stakeholders involved in the process of development of incubating academic firms, combined with general economic objectives the achievement of which justifies public spending on support of specific entities. The analysis was conducted on the basis of results of empirical research based on the case study strategy carried out among companies developing in such centres in Poland in comparison with more developed countries, including the UK, Belgium and Ireland. The presented analysis is based on the process approach in the framework of which characteristic stages of business development are distinguished, since the company's establishment to the point when it gains the potential for global development.

\section{Theoretical background}

\subsection{Commercialisation process of business ventures}

Commercialisation of research results, scientific achievements and expertise in the market is the essence of academic entrepreneurship and - depending on the technological or personal context - can take diverse forms. To be able to talk about such defined commercialisation, there is needed a new portion of academic knowledge (a combination of new knowledge or a combination of new and old knowledge), as well as an (academic) entrepreneur who perceives an opportunity for its application and takes actions enabling the transformation of this academic knowledge into economically useful knowledge and finally its market implementation. Effectiveness of the use of knowledge resources is measured by the difference between expenditures (public and private) incurred for their creation as well as effects obtained from their transformation [Lange, 1980]. Those are in general microeconomic terms revenues from sales [including the so-called innovation rent [Chen, 2009; Mazzarol, Reboud, 2009], and from the general economic perspective - the socio-economic growth and development [Romer, 1986]. In a wider perspective, commercialisation refers to the action undertaken in the search for a market opportunity associated with the use of new knowledge, acquisition and protection of this knowledge and resource configuration that enables its market implementation.

Given the context of academic entrepreneurship, it can be concluded that with respect to commercialisation of knowledge, there are two interrelated systems. It is schematically shown in Figure 1. One system is associated with commercialisation of intellectual property and the other with commercialisation of business ventures. Although both produce similar economic effects, they differ in terms of the balance of power and areas of impact on the processes taking place within. Other entities are engaged in commercialisation of intellectual property (the scientist - the university - the entrepreneur) 
- where knowledge is commercialised by its codification, objectification and sales, than the ones that are involved in commercialisation through entrepreneurial activities (the university - the entrepreneur - the investor) - where the focus is on identifying a market opportunity and the use of knowledge in a way that allows its application. Some entities are elements of both systems, which determines their close connection. It follows that commercialisation of business ventures is very different from commercialisation of intellectual property.

\section{Systems of commercialisation}

FIGURE 1.

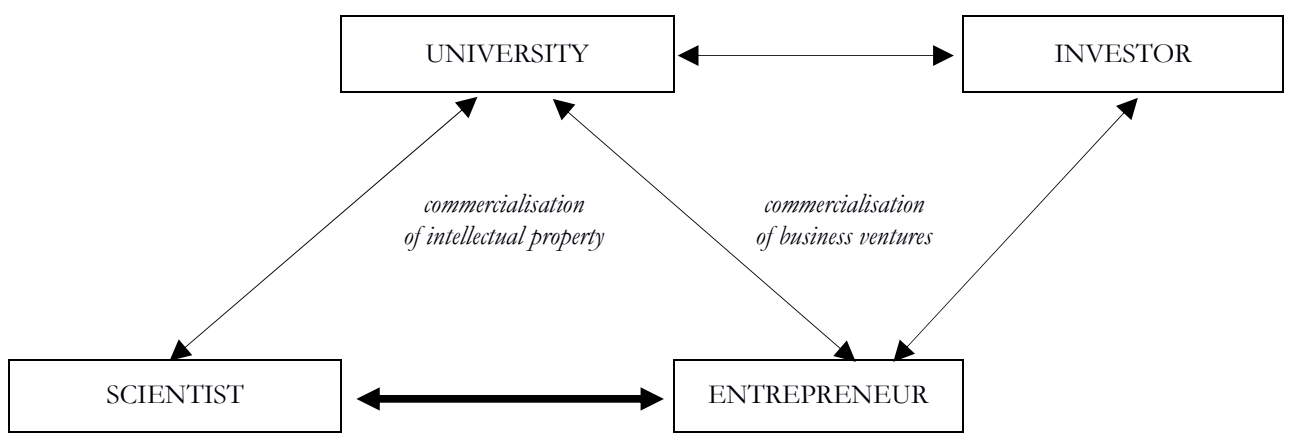

Source: [tobacz, 2012]

Commercialisation of business ventures is thus linked to actively undertaking entrepreneurial activities. If academic entrepreneurial activity is seen in terms of a process, this process can be defined as aimed at building a product concept and its link with the process of transforming technological knowledge can be indicated. Based on the in-depth analysis ${ }^{2}$, a model encompassing entrepreneurial activities in connection with commercialisation of knowledge, which is the basis for creating new market offers, was developed.

Since entrepreneurial activities are considered in relation to innovativeness, it seems appropriate to define activities related exclusively to transformation of knowledge into its economically useful form and then relate it to the entrepreneurial processes scheme. As the process should have an outcome defined at the end, the effects of actions related to creating a product concept are also included in the model. Based on those assumptions the process of development of the market offer has been described as consisting of three separate but strictly interconnected layers (Figure 2):

- activities aimed at creating a product concept associated with transformation of technological knowledge which result in innovation;

\footnotetext{
2 A detailed analysis is provided in: [Łobacz, 2012].
} 
- activities aimed at building a venture concept related to transformation of a market opportunity based on market knowledge which result in a market offer;

- activities aimed at building organisational competencies related to transformation of resources by using business expertise which result in organisational competencies.

FIGURE 2.

\section{Layers of the process of commercialisation of business ventures}

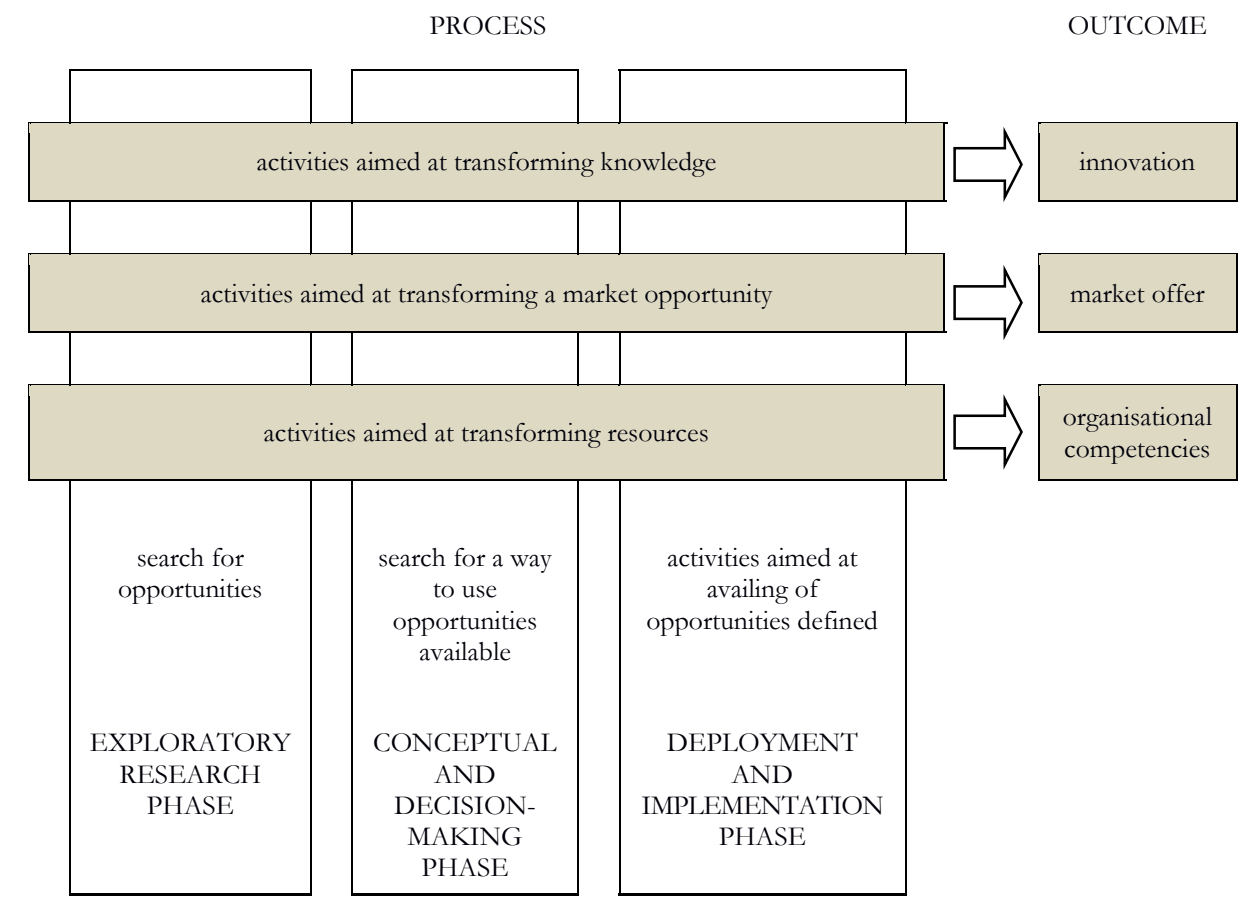

Source: [Łobacz, 2012]

Determining characteristics of individual layers of these processes and their analysis over time allowed the identification of five phases in the development of ventures related to launching successive products onto the market, associated with their innovativeness. It may be noted that the nature of the subsequent deployments, and thus the proposed market offer and knowledge used in their implementation, changes along with the development of capabilities and competencies of the company. In the subsequent phases, the approach to obtaining resources (including knowledge) and 
the method for their configuration also change. Taking this fact into consideration, the following phases of business development are distinguished ${ }^{3}$ :

- Phase 1: preparing a basic offer - which is related to hatching and initiating implementation of one's own vision of the venture; knowledge acquired through education and/or research and teaching work is commercialised; its transformation into a market product is a response to a market opportunity perceived through pursued interests and hobbies as well as being in the environment in which unmet needs are revealed, the business approach is usually typical, without any special features.

- $\quad$ Phase 2: improving the offer - occurs when entrepreneurs improve their offer, expand it, creating a portfolio of products (mainly service ones); these products are modified on the basis of improved knowledge and it is a customerdriven process as customers require solutions that meet their expectations; market opportunities are perceived through frequent contacts with customers and their communicated needs, on this basis a catalogue of products offered is created; the business approach remains typical, it is, however, more suited to customers' needs.

- Phase 3: building partnerships - occurs as a result of changes in philosophy of thinking about business; the offer takes the form of increasingly complex approach to issues related to needs that the company meets; it results from exploration of new possibilities (e.g. the search for new technological knowledge) as well as increasingly better understanding of market needs which can be met better than they currently are; limited resources make partnership crucial; it enables easy and flexible access to resources, especially ensuring provision of competencies which the company lacks.

- Phase 4: standardisation - is based on an expanded partnership; internal knowledge and partners' knowledge is used to create unique products; out of the catalogue of offers those that are rated as the most effective are implemented; there is a tendency for their standardisation.

- Phase 5: intense development of innovation - the transition to this phase requires the involvement of the company in their own targeted R\&D activities; the offer is prepared for the needs of broad markets, at least on a national scale, but mostly on an international one (sometimes over a slightly longer time horizon; a gradual entry to new markets); the key to success is access to substantial financial resources (the company's own or external ones) needed for marketing and sales, sometimes also R\&D activities.

Each phase is associated with implementation of a new market offer, however, it is possible to implement several offers at the same phase. This also means that each phase can last for an unlimited amount of time. The subsequent phases are associated with increasingly higher innovativeness, along with the development of companies it is therefore possible to commercialise increasingly advanced specialist (technological)

\footnotetext{
3 The description of business development based on the indicated stages and the genesis of their determination is shown in detail in: Lobacz [2012].
} 
knowledge. The further the stage of development, the more the scale of innovativeness of products offered shifts from incremental towards breakthrough one. Not only the idea but also knowledge on which it is based are subject to evolution. This, among other things, allows the company to create more advanced products.

\subsection{University business incubators and their support for the process}

University business incubators are seen as strategic tools of commercialisation of business ventures by universities. The strategic perspective, meaning not only commercialisation of the venture based on academic knowledge but also the potential for development on the basis of its rapidly forming new elements, is important in this respect. From this perspective, university incubators are accelerators of entrepreneurship based on new knowledge.

In general, incubators can be defined as entities established to coordinate the development of young companies, offering support services for business ventures and access to office space, which allows to achieve the company's objectives [Salman, Majeed, 2009]. The package of services offered by business incubators seeks to ensure the survival and growth of companies, thus maximising their impact on the economic development [Duff, 1998]. The above-presented definitions apply to the general concept of incubators, including characteristics of business incubators as such, without taking into account specific tasks that are associated with the operation of university incubators or technological incubators.

The distinction between university and technological incubators is not easy. In both cases, high significance of relations with research institutions and functioning in their proximity is indicated [Matusiak, 2010a; Ratinho, 2011]. Defining technological incubators, one more often draws attention to commercialisation of codified knowledge, resulting in new products [Matusiak, 2010a], whereas in the case of university incubators commercialisation of ventures based on the provision of services is more often referred to [Matusiak, 2010b]. Practice shows, however, that in the end such a division does not determine selection criteria, allowing ventures with the right profile into the incubator project. Sometimes university business incubators also include incubators created for the purpose of carrying out simple student ventures, as described based on examples of polish incubators by Matusiak [2010b]. This feature cannot be treated in permanent terms as the tendency to merge their activity profiles can be seen [Ratinho, 2011].

The essence of university incubators lies in supporting the university's activities in terms of commercialisation of business ventures that transfer academic knowledge into the market ${ }^{4}$. The type of transferred knowledge (overt-hidden), the resulting nature

\footnotetext{
${ }^{4}$ Such an approach to the function of university business incubators is also reflected in Polish legislation. According to the Act of 27 July 2005 Law on Higher Education Journal of Laws 2005, no. 164, item 1365 as amended], the university business incubator is an entity related to the university, operating as part of the university or as a separate commercial company [Art. 86 para 3], which may be the sole property of the university or its ownership can be shared with other entities [Art. 86a para 1]. Regardless of the legal form, the created entity is responsible for the commercial "use of the university's intellectual and technical potential" [Art. 86 para 1] and "transfer of research results to the economy" [Art. 86 para 1] through "support for entrepreneurial activities of academia" [Art. 86 para 2].
} 
of the venture (product based-service based), as well as the status of an individual entrepreneur (a student, a graduate-researcher, a Ph.D. student) do not matter in this respect. There are known examples of successful university incubators based on all four types of undertakings [Clarysse et al., 2005] as distinguished by Pirnay et al [2003], i.e. (1) product-oriented university venture, (2) service-oriented university venture, (3) product-oriented student venture, (4) service-oriented student venture.. The criterion of selection should be based on the relationship with the university and the degree to which it contributes to the achievement of its objectives. The issue related to the proximity of the location, which is related to the infrastructure of the premises occupied, is also important. Therefore the following definition is adopted: the university business incubator [UBI] is an entity occupying separate premises where ventures implemented by academia, organised by universities in order to commercialise academic knowledge through implementation of entrepreneurial activities and thus develop the entrepreneurial mission of the university, can be developed.

Objectives of university business incubators are mostly determined by the structure of the shares of institutions that organise these entities. Lalkaka [2000] distinguishes various objectives for the achievement of which incubators strive depending on their ownership structure (table 1). Since the organisation of proper infrastructure is associated with high expenditures and also requires additional operating expenses related to its maintenance, owners expect a return on investment in the form of significant benefits. Incubators often have several different shareholders/founders, which on the one hand leads to their strengthening due to the combined impact of many forces, but on the other hand means that they aim at achieving different objectives [Salman, Majeed, 2009].

\section{Types of incubators and their objectives}

TABLE 1.

\begin{tabular}{|c|c|}
\hline Leading/financing institution & Objectives \\
\hline universities & $\begin{array}{r}\text { innovations, commitment on the part of } \\
\text { academics and students }\end{array}$ \\
research institutions & research commercialisation \\
governments/local authorities & $\begin{array}{r}\text { regional/economic development, job } \\
\text { creation, poverty prevention }\end{array}$ \\
private sector & profits, patents, spin-off companies, image \\
\hline
\end{tabular}

Source: [Lalkaka, 2000].

With regard to public entities, which are also the incubator's founders, one can point out a certain contradiction associated with combining commercial and non-commercial objectives. If the entrepreneurial orientation of the university is to be an exclusively social function, it should be fully subsidised from the state budget. If, however, the university is to become a business entity and partly raise funds for its activities from 
the economy, incubators must be a source of capital and allow the achievement of its objectives.

From the point of view of the university, financial and non-financial objectives can be distinguished. Among financial objectives, obtaining further funds for research and revenue from the sale of intellectual property should be mentioned ${ }^{5}$. Non-financial objectives include raising the prestige of the entity and extending its impact as well as establishing research collaboration [Price et al., 2008]. Building a reputation and strategic cooperation also indirectly translates into financial benefits (e.g. associated with increasing the number of students or attracting private capital for implementation of research tasks). From the perspective of the private sector, profit-driven orientation is important, profit which can be achieved in the short or long term. The revenue relates to the functioning of incubated companies as well as investors engaging private capital in their development. Orientation towards the rapid development of companies, their independence and the return on investment is one of the strategies used by incubators [Wright et al., 2007].

In practice, intensive national and European innovation policies make incubators public-private entities. Thus, their objectives need to coincide with socio-economic objectives. From an economic point of view, great importance of university business incubators in supporting the creation and development of new businesses is primarily indicated [Sherman, Chappell, 1998], which is reflected, for example, in encouraging potential entrepreneurs to start their own business [Aernoudt, 2004] by providing them with services supporting the development of business, marketing, management, capital raising, legal counselling and access to services and infrastructure that can be shared between companies. According to the European Commission [2002], incubators should accelerate and systematise the company's development. They should also support ventures characterised by high growth potential, creating jobs and increasing social welfare. At the same time, an important socio-economic role of incubators in ensuring the survival of new business, which need special targeted support for proper development [Lalkaka, 2000], is indicated. For example it is said that approx. $80 \%$ of newly created businesses fail in the first five years of operation [Salman, Majeed, 2009]. Thus, effective support for businesses at an early stage of their operations, shortening their learning curve, and assistance that enables their survival are considered essential. This approach reduces incubators to the role of purely business environment institutions [Markiewicz, 2010]. Whereas from a socio-economic point of view, one should pay attention to the role of university incubators in commercialisation of knowledge generated and transferred at universities, as well as the involvement of private capital in financing research and development activity [UKBI, 2012], which is one of the most important objectives of the current innovation policy [Strategia lizbońska, 2002; Unia Innowacji, 2010].

${ }^{5}$ According to the Polish Act of 27 July 2005 Law on Higher Education, the university can obtain profits through establishing, by means of specially set up targeted companies (limited companies), capital companies created for the purpose of "implementation of research results or research and development activities conducted by the university" [Art. 86a para 1]. The university can allocate dividends paid on activities of the targeted company to its statutory activities [Art. 86a para 4]. 
It should also be noted that there is a lack of conceptual consistency in terms of the definition used by authorities conducting the policy. On the one hand, it is said that incubators are important for the survival of companies, but on the other hand the high potential and dynamic growth of these entities are mentioned. These two approaches appear to be contradictory, for example, in relation to evolutionary models of Nelson and Winter [1982]. According to the evolutionary theory, supporting companies that otherwise would not survive is just unnecessary prolongation of their agony. And indeed, one can list many examples of companies that have ceased to exist shortly after leaving the incubator [Freeman et al., 1983]. However, support for companies with a high growth potential in the initial period, when it is necessary to incur significant expenditures on R\&D activity to prepare a product for sale, is entirely consistent with objectives of the science and innovation policy. Therefore, strategies implemented by incubators usually include one of the following objectives [Wright et al., 2007]:

- economic, i.e. focused on generating profits and rapid business growth,

- $\quad$ social, i.e. focused mainly on the creation of new jobs (employment growth).

Regardless of the adopted social or economic perspective, university business incubators are established in order to assist in creating jobs and prosperity as well as to counteract regional economic problems and support commercialisation of new ideas and research results derived from universities and companies [Wright et al., 2007].

Numerous studies emphasise the importance of activities carried out by university business incubators [Kowalczyk et al., 2011]. The need to improve their quality [Albert, Gaynor, 2003] as well as to eliminate barriers that hinder the performance of these activities [Ośrodki innowagij..., 2009 and 2010] is widely indicated. The question arises, however, how these activities relate to objectives set for university business incubators from the perspective of key stakeholders and the economy. Taking into account interests of key stakeholders of knowledge commercialisation through implementation of business ventures (which is important from the point of view of their involvement), as well as economic objectives, requires incubators to focus simultaneously on three main objectives:

1. Commercialisation of academic knowledge.

2. Ensuring the survival and growth of companies.

3. Increasing investment capital involved in commercialisation of knowledge.

Striving to achieve such a bundle of objectives is indicated as a development trend of incubators [Ratinho, 2011]. They comply with the definition formulated by the UK Business Incubator [UKBI, 2012] stating that it is a dynamic process of business development aimed at supporting rapid growth of businesses and their survival, assistance in identifying investment opportunities and support for commercialisation of new knowledge. In addition, an important role of incubation in creating jobs and wealth, as a way to counteract problems related to the economic development, is indicated. To achieve this, the incubator can affect the process of commercialisation of business ventures, providing adequate involvement of stakeholders. Previous analyses, however, focusing on supporting companies, often ignore the importance of universities and investors in the process of commercialisation of knowledge, thus ignoring objectives important from their point of view. Tasks of business incubators 
are generally considered only in relation to the added value generated for companies [Campbell et al., 1985]. However, taking into account objectives defined for university business incubators, the added value is important for each entity involved in the process, as well as for the economy.

\subsection{Stakeholders of the process and their interests}

The above-presented considerations indicate that university business incubators are expected to provide effects on the economic and individual level. There is, therefore, the need for balanced integration of objectives and expectations of key stakeholders [Ratinho, Henriques, 2010; OECD 1997]. It has been pointed out that such integration has a positive effect on effectiveness of activities carried out by incubators [Quinn, Rohrbaugh, 1983]. It is a condition necessary for stabilisation of the system, ensuring effectiveness of its functioning [Niedzielski, 2003]. Appropriate targeting of individual objectives will allow the achievement of general economic objectives. The relationships between objectives are presented in Figure 3.

FIGURE 3.

The role of university business incubators in the system of commercialisation of business ventures

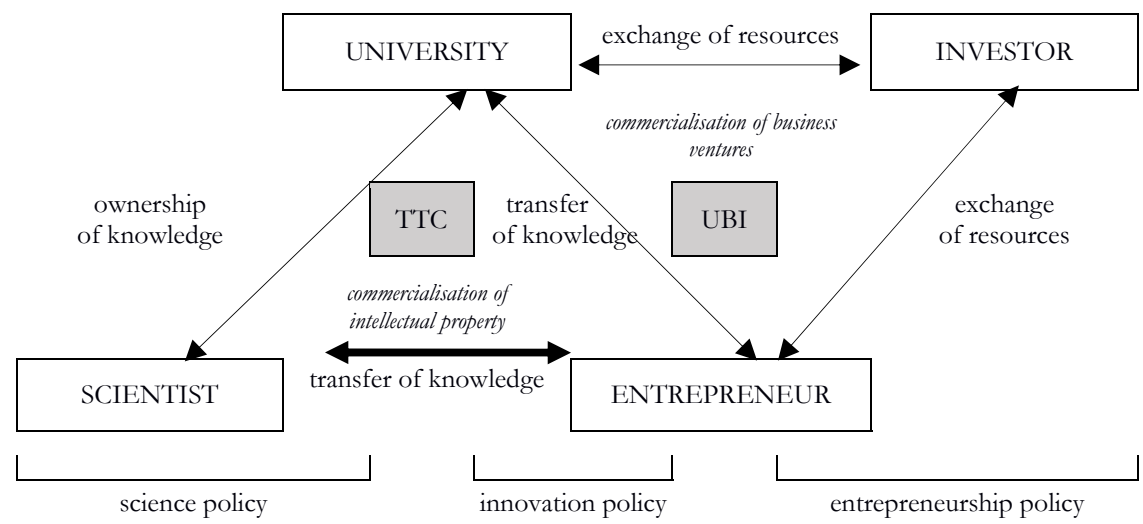

Source: [Łobacz, 2012]

The presented diagram of stakeholders ${ }^{6}$ and their objectives, which are translated into objectives of university business incubators and as a consequence into economic objectives,

\footnotetext{
${ }^{6}$ A similar diagram of stakeholders is presented in the analyses of Mcadam et al [2006]. They also take into account the significant interest of local authorities at the local and national level. In this study, local governments are, however, seen in the role of coordinators of economic objectives and they are included in the analysis in a subjectless manner.
} 
corresponds to the presented diagram of the systemic approach to commercialisation of knowledge in the university context (Figure 1). It takes into account key stakeholders of knowledge commercialisation and relationships existing between them. In relation to this system, the important role of university business incubators as coordinators of the system of commercialisation of business ventures can be seen (Figure 3). University business incubators, acting in conjunction with technology transfer centres, are designed to ensure the smooth functioning of the system of commercialisation in which objectives of stakeholders involved are achieved and (as a result) also general economic objectives [Trzmielak, 2011]. In contrast to tasks of university business incubators, the main tasks of technology transfer centres, as emphasised by Matusiak, include "informing about research work conducted at universities and the search for opportunities to sell research results, as well as the search for partners or customers for the next project" [Innowacje i transfer technologii..., 2011].

From an economic point of view, the university is only one element of the system which needs relationships with its other participants for its smooth functioning [Clarysse et al., 2005]. It should be assumed that the other entities will participate in the processes related to the functioning of the system, i.e. they will be willing to allocate their resources (time, financial and material resources, knowledge) if this allows them to achieve their own objectives. Thus, the task of university business incubators is such coordination of objectives of key stakeholders (including, in particular, universities, entrepreneurs and investors) so that they would contribute to achieving general economic objectives. Then commercialisation of knowledge through implementation of new business ventures will have individual as well as economic significance.

Despite the apparent convergence of objectives of different stakeholders, they can be achieved at different levels. In addition, the achievement of these objectives also translates into socio-economic benefits. Focusing on one objective or on a number of selected ones is a common practice. This applies to university business incubators as well as to politicians that design support instruments. It can, therefore, be assumed that ventures developing in university business incubators may be focused on specific objectives to varying degrees. Given the systemic nature of the commercialisation process of business ventures presented in Figure 4, it can be indicated that university business incubators have an impact on this process. Thus they may affect the achievement of specified objectives.

Since the smooth functioning of the systems also translates into the achievement of economic objectives at different levels, they remain in the area of the interest of politics. The overlapping of policies related to the stimulation of science, innovation and entrepreneurship necessitates their integration in order to be able to support the system of commercialisation of business ventures. The division of policy areas presented in Figure 3 is inspired by the Landstrom et al. [2008], adapted into the Polish conditions by Stawasz [2011]. 
FIGURE 4.

\section{Objectives of the functioning of university business incubators in relation to different groups of stakeholders}

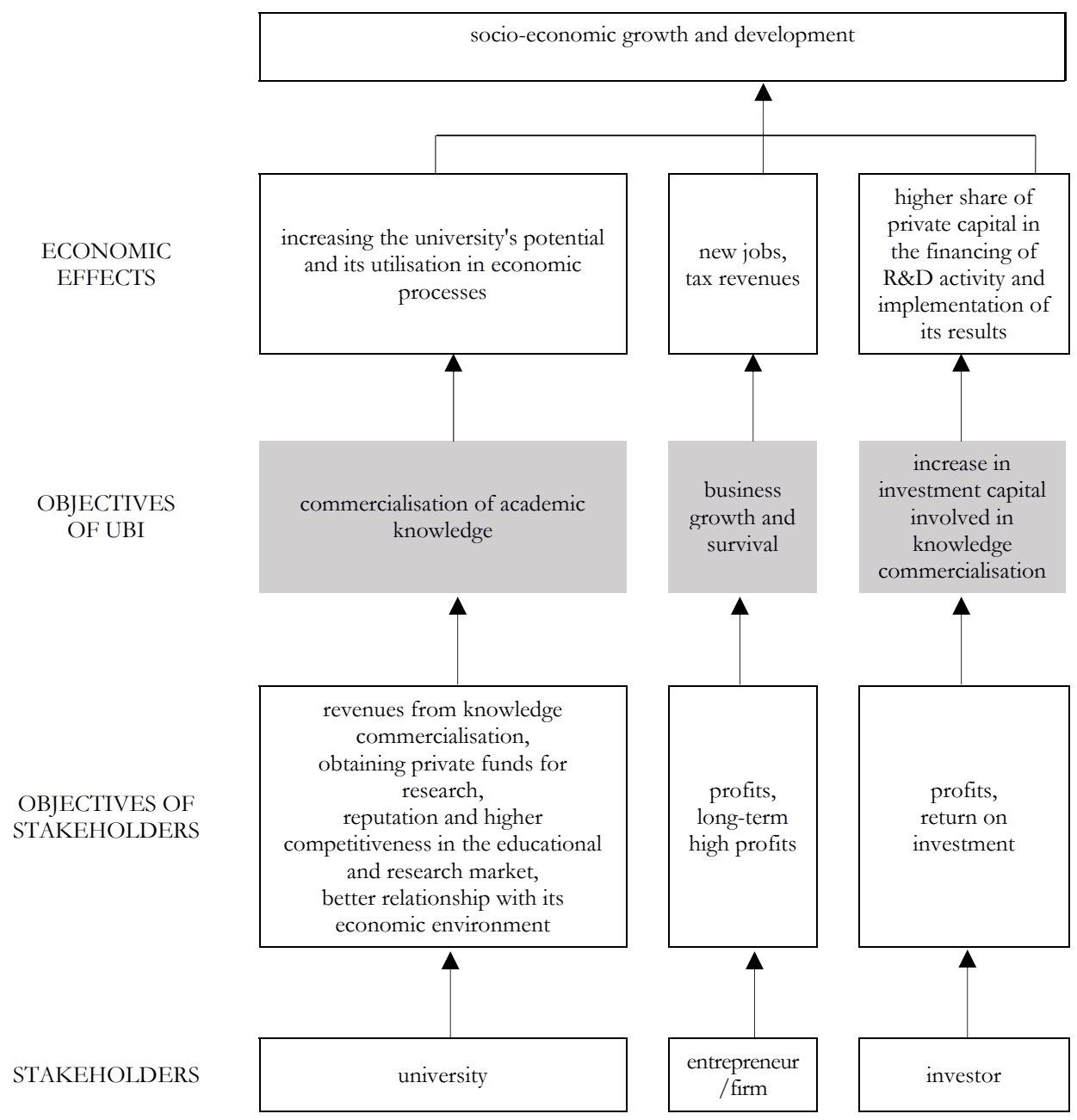

Source: [Łobacz, 2012]

Although commercialisation processes are often associated with involvement of a large number of entities [e.g.: training companies, consulting firms [Ratinho, 2011; [Kowalczyk et al., 2011]], the presented system (Figure 3) includes only entities whose participation in the process is, firstly, direct, and secondly is of the investment nature [Price et al., 2008], (the expected return on activities conducted occurs only after some time and is not certain). Their participation is therefore associated with calculation - 
evaluating profitability of the investment and its perception in strategic terms. The same applies to actions taken by the state which also invests through the system of grants and subsidies, expecting to receive a return over a certain time horizon. The use of network mechanisms to create value from innovation activities is recently indicated as a modern development trend [Niedzielski, Łobacz 2011].

Resource allocation is also associated with knowledge which in the case of all the related entities is of a strategic nature. It should be noted that every entity in the system is both a donor and a recipient, also a donor and a recipient of knowledge:

- The university is a donor of scientific knowledge, theoretical business knowledge, sometimes know-who, as well as a recipient of knowledge related to market demand for new solutions and educational programmes.

- The investor is a donor of practical business knowledge, including its most precious element - know-how and know-who, as well as a recipient of knowledge on new directions of the development of science and market opportunities.

- The entrepreneur is a donor of scientific knowledge and knowledge associated with a market opportunity as well as a recipient of scientific knowledge creating new market opportunities and business knowledge.

The university business incubator as a third partner is designed to play the role of a coordinator of resource exchange in this system. The tasks which it should perform in order to achieve these objectives ought to be indicated.

\section{Research methodology}

Based on the presented model, objectives of various stakeholders of the commercialisation process of business ventures in conjunction with general economic objectives have been analysed. Extensive literature studies concerning all university business incubators in Poland and selected incubators in developed countries of Europe were conducted. With their support, cases of companies developing within university business incubators in Poland were then analysed in comparison to companies from the UK, Belgium and Ireland. According to the classification presented by Yin [1982], the multiple case study model was adopted, recognised as a valuable approach in the study of small businesses [Chetty, 1996], mainly due to the ability to analyse single or complex research problems in the environment rich in variables affecting the context of operations [Eisenhardt, 1991].

Within the framework of the study, individual in-depth interviews were conducted [Oppenheim, 2004]. The formula of a narrative interview, using communication techniques, was adopted in order to focus the conversations on issues related to the subject of the study, at the same time assuming the greatest possible freedom of expression. In-depth interviews were conducted with owners or general managers of small innovative companies developing within university business incubators. The contents of individual interviews were recorded on digital media, which allowed them to be played back at the stage of data analysis. The theoretical sampling method was used [Yin, 1989; Eisenhardt, 1991]. Selection of further cases was carried out until saturation 
of theoretical categories was achieved, without initial assumptions relating to their number. This procedure is consistent with the concept of the grounded theory of Barney and Strauss [Glaser, Strauss, 1967], assuming the selection process of further cases in order to compare them with those that have already been analysed. Finally, 52 cases of companies were analysed.

Conclusions from the study are shown below in the aggregate form, i.e. compiled results of all the studies presented broken down according to the logics of conclusions drawn. Those are drawn based on doctoral dissertation of the author [Lobacz, 2012], where more detailed analysis of the problem is presented.

\section{Research results}

The analysis based on the staged process of development of companies in university business incubators allowed to link its effects to objectives of individual stakeholders of the process. Referring to the three main stakeholders of the process, three groups of support objectives pursued by university business incubators were identified:

- commercialisation of academic knowledge,

- the growth and survival of companies based on academic knowledge,

- an increase in investment capital involved in commercialisation of knowledge.

It has been assumed that achieving each of these objectives has a positive impact on economic effects [increasing the university's potential and its use in economic processes, new jobs, tax revenue, increasing the share of private capital in financing research and development activity and implementation of its results] having a bearing on the economic growth and development. It has been pointed out that the achievement of these objectives is conditional on the involvement of key stakeholders in the process, which, in turn, is dependent on the effects that these entities can generate as a result of the process. Therefore, three groups of objectives crucial to the process of commercialisation of business ventures in university business incubators have been identified:

- objectives of universities: revenues from commercialisation of knowledge, raising private funds for research, gaining reputation and increased competitiveness in the education and research market, improving ties with the economic environment;

- $\quad$ objectives of entrepreneurs (the company): profits, long-term good performance;

- objectives of investors: profits, return on investment.

These aspects were analysed in terms of the process approach and schematically presented in Figure 5. The lack of contradiction between objectives set by key stakeholders is an important conclusion drawn from this approach to the issue. It can be said that commercialisation of a larger amount and more advanced knowledge (one of the main objectives of the university) positively affects businesses' performance as well as private investors' willingness to commit resources to their development. This, in turn, determines the motivation and abilities to take actions oriented towards commercialisation of another portion of knowledge. It is possible only when certain conditions are met (e-.g. when the entrepreneur has sufficient business knowledge). 


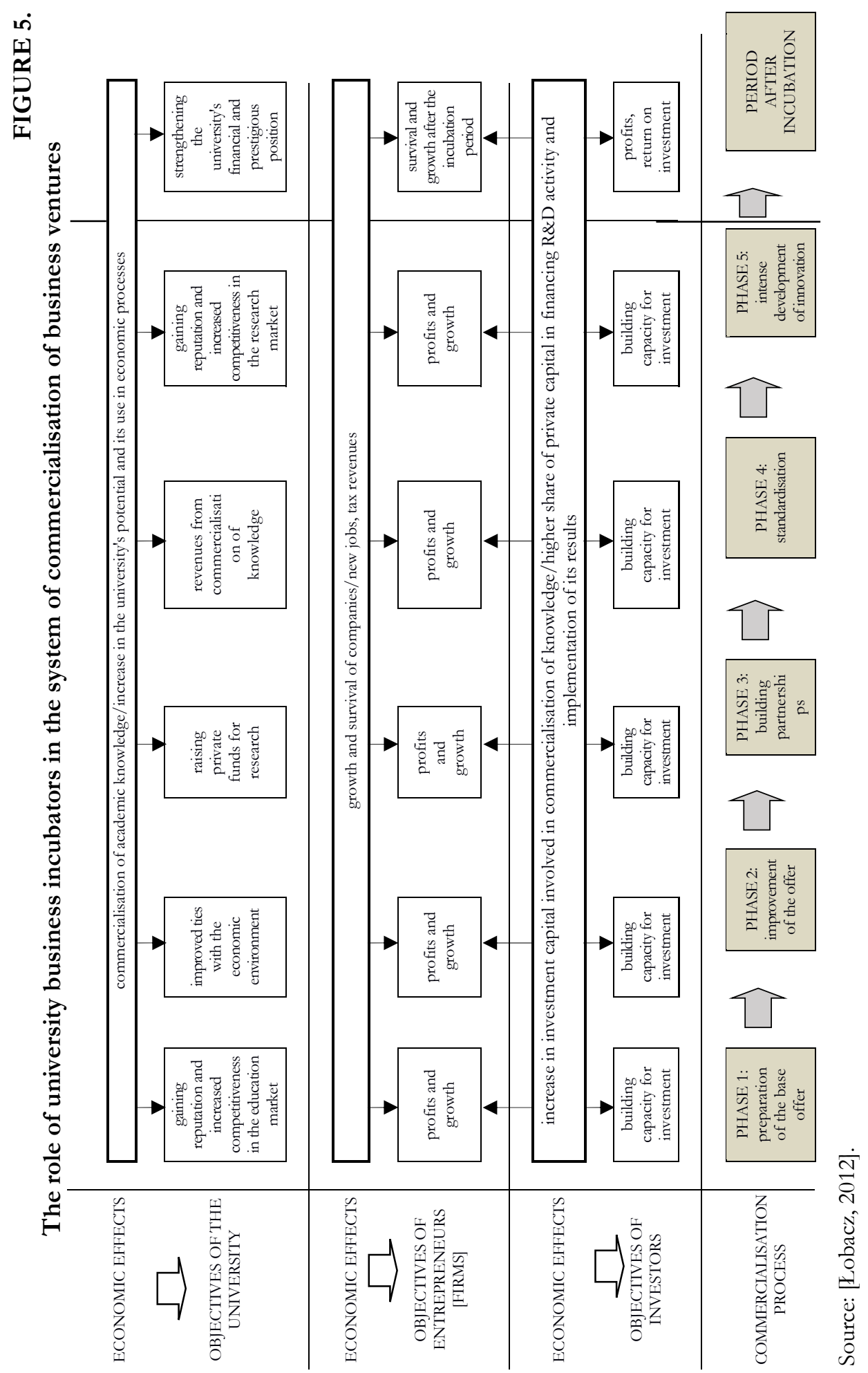


In the case of the process of development of business ventures in university business incubators, it can be said that entrepreneurs contribute with their activities to the attainment of all objectives simultaneously. It should be noted, however, that it does not occur in a parallel manner but is assigned to the stages of development of ventures and depends on the strategy adopted by an entrepreneur. This applies in particular to the university's objectives related to commercialisation of knowledge. The transition between the subsequent phases in each case is closely connected with commercialisation of knowledge but it is not necessarily knowledge which has its source at the university.

It can be said, therefore, that the transition between the subsequent phases of the process means the ability to achieve the stated objectives, however, whether this occurs depends on many factors, for example, on entrepreneurs' access to knowledge or presence of adequate knowledge resources. Thus, it seems that university business incubators can play an active role in stimulating activities that lead to achieving the stated objectives, for example, by providing access to knowledge accumulated by the university - whether in the form of tacit or explicit knowledge that can be commercialised. This also applies to implementation of appropriate criteria for selection of business ventures for incubation support, aimed at selecting those ventures that are strongly associated with the university's activity profile (in practical terms, selection not guided by political correctness, as is often the case).

The analysis of Figure 5 also indicates that various objectives are achieved as a result of implementation of the process. The diagram shows the point at which the objective is achieved in absolute terms. However, it can be also noted that the level of achievement of the objective increases over time. For example, revenues from commercialisation of knowledge may increase as a result of the entrepreneur's success (if a license agreement for the use of a new technology is signed, the seller obtains financial benefits in the form of a percentage of revenue obtained by the buyer), they may also be increased by the multiple sale of intellectual property rights by the university. The same applies to profits and growth of companies which increase over time.

The presented considerations also indicate that the achievement of stakeholders' objectives is only possible when they are engaged in the process. For example, gaining reputation and competitiveness in the education market will be possible only if the university implements appropriate programmes focused on entrepreneurship from which budding entrepreneurs will be able to draw knowledge and inspiration to take action towards commercialisation of knowledge. Creating the environment from which potential entrepreneurs derive their first ideas and business contacts is one of the key factors that have an impact on undertaking entrepreneurial activities. Similar conclusions can be applied to investors for whom obtaining profits is the result of investment decisions taken at the fifth phase of the process.

Thus, despite the assignment of the possibility of achieving objectives to the subsequent phases of the process, it is not done in an automatic way. Whether the university achieves its objectives depends essentially on two factors: the relationship between the entrepreneur and the university, as well as the willingness on the part of university staff and the university itself to cooperate. In turn, investors' objectives can be accomplished if there is a meeting between the investor and the entrepreneur 
accompanied by a mutual exchange of expectations. This shows great importance of the creation of network relations in the course of the process, which was included as one of the important tasks of university business incubators.

Commercialisation of academic knowledge brings with it many implications leading to the strengthening of the university's financial and prestigious position and an increase in its capacity which should be used in economic processes. It should be noted that it is carried out not only as a result of implementation of the subsequent phases of the process but through successive iterations in the framework of individual stages. This applies particularly to raising private funds for research as well as revenues from commercialisation of knowledge. There may in fact be situations in which at each subsequent iteration at a given phase of the process the sale of another portion of intellectual property will occur, which will result in multiplication of revenues. Generally, one can therefore say that more iterations mean commercialisation of a larger portion of knowledge (provided that at each iteration a new portion of knowledge is commercialised). At the same time - due to the variety of objectives assigned to the subsequent phases and also to the fact that specialisation of commercialised knowledge increases along with the development of the venture - from the point of view of the university's objectives, the transition between the subsequent phases is important.

The objective associated with investing funds (the investor's objective) is achieved at the fifth phase but all the previous phases form its foundation. It should be noted that, in some cases, an investment may also occur at an earlier stage but then commercialised knowledge is not highly specialised and is associated with the possibility of obtaining smaller profits yet carries a lower risk.

The objective of entrepreneurs, as indicated earlier, is, however, achieved at each stage of development, with increasing intensity. Case studies show that, with multiple iterations within the same phase, there is some stability to implemented measures and profits. However, prolonged repetition of these actions leads companies into the trap of lack of growth and loss of ability to resolve the stalemate. In turn, the development and an increase in the level of profit is possible due to the transition to the subsequent phases of the development. In carrying out their activities, entrepreneurs also invest capital in commercialisation of knowledge. Despite the small scale of these investments, their importance should be seen as significant in terms of increasing the participation of private capital in financing R\&D activity and implementation of its results.

\section{Conclusions}

The analysis based on process approach indicates that objectives associated with survival and development of firms. It has been observed that lack of development and transition to the subsequent phases means the collapse of the company after a certain period after foundation. Therefore, the focus on the current situation and repeating schemes of actions within the same phase of development leads to stagnation, exhaustion of the potential and consequently to the company's collapse after a longer (in the case of more stable markets) or shorter (in more dynamic markets) period of time. It 
has been indicated that companies are able to expand their business activities in the incubation period of 2-3 years, passing through all the five phases. To make it possible though, coordination of factors affecting this development is needed. Thus, slow growth of businesses in some incubators is usually an indication of their business failure soon after the end of the incubation period and objectives of individual stakeholders as well as general economic objectives are achieved at negligible levels (usually ending at the second phase).

Furthermore, due to their potential to innovate and grow, ventures developing within university business incubators can contribute to achieving a variety of economic objectives, thus responding to objectives set by stakeholders. To do this firms need flexible access to resources which can be provided by all stakeholders. This means that stakeholders, including universities, can stimulate activities aimed at accomplishing their objectives through direct involvement in the process and thereby target better activities undertaken by companies in university business incubators.

At the same time, the research results based on the process model indicate that there is no contradiction between objectives of individual stakeholders of the process and general economic objectives. The stage-based process of commercialisation of business ventures indicates that the transition between the subsequent phases enables the achievement of successive objectives, both economic and individual. The level of achievement of particular objectives may, however, depend on flexible access to resources. This access can be actively supported by business incubators adequately to phase of development of particular venture or group of ventures.

Referring the analysis to the presented layers of the process, it seems that the key to achieving objectives is the layer of knowledge transformation. For example, whether and which objectives are achieved by the university is determined by whether and what kind of knowledge is commercialised. This, in turn, determines the transition between the subsequent phases of development, and thus means profits for companies and investors. The other layers, however, affect the level at which the transformation of knowledge can take place. For example, knowledge alone is not enough to be able to obtain venture capital financing, as adequate resources and business skills that will affect the success of commercialisation are also required. Thus, also appropriate business competencies, market knowledge and other physical and human resources, which are accumulated at the subsequent phases, are needed in order to achieve the set objectives.

On the other hand, a company may perform well with very little academic knowledge or lack thereof. With the adoption of an appropriate business model, a company may also get financial support from an investor. This means that the university may drop out of the value chain, which may limit the economy in terms of growth. New knowledge that arises in scientific units is not included in the economic cycle and does not create new market opportunities. Thus, it seems that the focus on all stakeholders simultaneously achieving their objectives should produce the most optimal - from an economic point of view - effects. A lack of contradictions between their objectives should therefore be the basis for providing support (e.g.: through university business incubators) to achieve objectives important for universities. 


\section{Discussion and implications}

The studies described in the paper provide the evidence that the potential of university business incubators is in fact not fully utilised by all stakeholders of the commercialisation process of business ventures, which is confirmed in other studies of the European area, although it is indicated that incubators are potentially an effective tool of the innovation policy. Ratinho [2011], examining where companies based in business incubators seek assistance in solving their problems, state that there are three such sources: the incubator (the incubator's administration), other companies located in the incubator and external network contacts. Based on statistical analyses, they also show that support is mainly sought outside the incubator. Interpreting the results obtained, they point out weaknesses and limitations of the system of support offered by incubators, at the same time calling for better adaptation of services to real needs of companies (along with their growth and development, businesses do not receive from incubators the support needed to solve their problems - incubators are not capable of providing it).

Another conclusion, derived from research of Ratinho [2011], confirmed by the conducted study, is lower demand for the incubator's support for entrepreneurs who already have experience in running a business. Burton et al. [2002] have also demonstrated that an entrepreneur's professional experience has an impact on the initial strategy adopted in implementation of a venture. According to these authors, experience determines the way of thinking about the market and the business, as well as the ability to obtain specific resources. This relation, according to the research results presented in the paper, also has a significant impact on the transition through the subsequent phases of development. Ratinho [2011] draws attention to importance of selection criteria for ventures chosen for support. At the same time, demand for support has an impact on indicators related to effectiveness of actions taken by incubators.

Although the results of research undertaken from the perspective of the process approach described in the paper show the same relationships, they suggest a different explanation. On their basis, it can be concluded that the demand for support is dynamic as it depends on the development stage of the venture. This means that along with increasing heterogeneity of the venture in its subsequent phases (in the early stages, activities are more homogeneous), the need for cooperation and specific (more specialised) support increases. This confirms great importance of learning through partnership, as indicated earlier by Yli-Renko et al. [2001] and building competencies through relations with other organisation, as elaborated by Grant and Baden-Fuller [2004]. The incubator, in accordance with the principles of effective functioning, is able to provide support of a more general nature. Therefore, one can interpret this relationship in the following way: in order to increase effectiveness of the support provided, incubators should focus primarily on creating opportunities (e.g. providing access to a network of contacts) rather than on developing a portfolio of services provided by their own employees. Effectiveness of support can then be considered in relation to how quickly companies become independent to the extent that assistance in their survival and development is no longer needed. After incubation, companies should be able and willing to continue cooperation with the incubator (which may derive further profits from this cooperation), 
as well as (and perhaps primarily) with networks of contacts established during the incubation process, including, among others, the university.

It should be noted that, in relation to objectives set (and their achievement), any policy will be largely ineffective if there is not enough social maturity. The analysis of guidelines that define the current policy of promoting entrepreneurship through university incubators, leads to the conclusion that the support is well targeted but the achieved results are far from expected. A good example in this case can be selection criteria of companies that are eligible to make use of the privilege of incubation. Despite the fact that the criteria follow in the wake of the needs regarding the university's objectives associated with commercialisation of knowledge, in practice their use proves to be very shallow. As a result, the flow of knowledge from the university to the economy is limited, there is also little involvement of funds provided by outside investors. The performance of companies is also not very impressive, although many of them have very high potential. Maturity of social capital is currently indicated as a key barrier in the system of commercialisation of knowledge and technology transfer, which has also found its reference here [Rekomendacje zmian..., 2011; Niedzielski, Łobacz, 2012].

It follows that the impact of university business incubators may be important for the development of companies, thereby contributing to generating economic growth. They can play an active role in stimulating activities whose driving force is striving to achieve the stated objectives. However, it should be noted that the scope of support needs is dynamic, changing along with maturity of companies and their transition to the subsequent stages of development. This means the need to adapt support to changes taking place in the course of the development of companies so that it can be effectively allocated.

\section{References}

Acs Z. J., Braunerhjelm P., Audretsch D. B., Carlsson B. 2009 The Knowledge Spillover Theory of Entrepreneurship, "Small Business Economy", no. 32.

Aernoudt R. 2004 Incubators: Tool for Entrepreneurship?, "Small Business Economics", Vol. 2, No. 2.

Agrawal A. 2001 University-to-Industry Knowledge Transfer: Literature Review and Unanswered Question, "International Journal of Management Reviews", Vol. 3, No. 4.

Albert P., Gaynor L. 2003 National Vontexts, Incubator Families and Trends in Incubation$V$ iews from four Countries, The 48th ICSB Conference Proceedings, Belfast.

Allen D. N., McCluskey R. 1990 Structure, Policy, Services and Performance in the Business Incubator Industry, "Entrepreneurship Theory and Practice", Vol. 15, No. 2.

Audretsch D.B., Aldridge T.T. 2009 Scientist Commercialization as Conduit of Knowledge Spillovers, "Annuals of Regional Science", No. 43.

Burton I., Huq S., Lim B., Pilifosova O., Schipper E.L. 2002 From Impacts assessment to adaptation priorities: The Shaping of Adaptation Policy, "Climate Policy", Vol. 2.

Campbell C. 1989 Change Agents in the New Economy: Business Incubators and Economic Development, "Economic Development Review", Vol. 7, No. 2. 
Campbell C., Kendrick R. C., Samuelson D. S. 1985 Stalking the Latent Entrepreneur: Business Incubation and Economic Development, "Economic Development Review", Vol. 3, No. 2.

Chen Ch. J. 2009 Technology Commercialization, Incubator and Venture Capital and New Venture Performance, "Journal of Busienss Research", Vol. 62.

Clarysse B., Moray N. 2004 A process Study of Entrepreneurial Team Formation: The Case of a Research-Based Spin-off, "Journal of Business Venturing", Vol. 19, No. 1.

Clarysse B., Wright M., Lockett A., Van de Velde E., Vohora A. 2005 Spinning out New Ventures: A Typology of Incubation Strategies from European Research Institutions, "Journal of Business Venturing", No. 20.

Duff A. 1998 Best Practice in Incubator Management, AUSTEP Strategic Partnering Private Limited, Western Australia.

European Commission 2002 Benchmarking of Business Incubators. Final Report, Brussels.

Freeman J., Carroll G. R., Hannan M. T. 1983 The liability of newness: age dependence in organizational death rates, "American Sociological Review”, Vol. 48, No. 5.

Grant R. M., Baden-Fuller C. 2004 A knowledge Accessing Theory of Strategic Alliances, "Journal of Management Studies", Vol. 41, No. 1.

Harman P., Read L. 2003 Supporting Incubation in the UK through the Development of Benchmarks, UKBI: International Council for Small Business, 48th World Conference, Northern Ireland.

Innowacje i transfer technologii. Stownik pojeć, 2011, K. B. Matusiak (ed.), edition III updated, PARP, Warszawa.

Janasz W. 2004 Innowacje w rozwoju przedsiębiorczości w procesie transformacji, Wydawnictwo Difin, Warszawa.

Kowalczyk I., Pawłowska J., Sarti F., Biasetti I. Z. 2011 Metody inkubacji projektón biznesonych, PARP, Gdańsk/Szczecin/Torino.

Kozmetzky G., Williams F., Williams V. 2004 New Wealth, Commercialisation of Science and Technology for Business and Economic Development, Praeger.

Lalkaka R. 2000 Assessing the Performance and Sustainability of Technology Based Incubators. New Economy and Entrepreneurial Business Creation in Mediterranean Countries, Trieste.

Landstrom A., Almerud M., Stevenson L. 2008 Entrepreneurship and Innovation Policies. Analysing Measuring in European Countries, "Swedish Foundation for Small Business Research", Stockholm.

Lange O. 1980 Ekonomia polityczna, PWE, Warszawa, Vol. I.

Łobacz K. 2012 Koncepcja oceny procesu komercjalizacji przedsięwriéć gospodarczych w akademickich inkubatorach przedsiebiorczości w Polsce, Ph.D. thesis, Szczecin

Lyons T. S. 1990 Birthing Economic Development: How Effective Are Michigan's Business Incubators?, Center for the Redevelopment of Industrialised States, Social Science Research Bureau, Michigan State University.

Markiewicz J. 2010 Instytucje otoczenia biznesu. Rola w ksztaltowanin innowacyjności sektora MSP na pr:zykładzৃie wojewódzৃtwa zachodniopomorskiego, WNUS, Szczecin.

Matusiak K. B. 2010a Inkubatory technologiczne, [in:] Ośrodki innowacï i przedsiębiorczości w Polsce. Raport 2010, K. B. Matusiak (ed.), PARP, Warszawa. 
Matusiak K. B. 2010b Preinkubatory i akademickie inkubatory przedsiębiorczości, [in:] Ośrodki innowacji i przedsiebiorczości w Polsce. Raport 2010, K. B. Matusiak (ed.), PARP, Warszawa.

Matusiak K. B., ed. 2009 Ośrodki innowacii i przedsiębiorczości w Polsce. Raport 2009, PARP, Warszawa.

McAdam M., Galbraith B., Mcadam R., Humphreys P. 2006 Business Processes and Networks in University Incubators: A Review and Research Agendas, "Technology Analysis \& Strategic Management", Vol. 18, No. 5.

Mian S. A. 1994 US University-Sponsored Technology Incubators: An Overview of Management, Policies and Performance, "Technovation", Vol. 14, No. 8.

Mian S. A. 1997 Assessing and Managing the University Technology Business Incubator: An Integrative Framework, "Journal of Business Venturing", No. 12.

Muent H. 1999 University Spin-offs and Local Business Support Infrastructure in a PostSocialist Economy, "Journal of Small Business and Enterprise Development", Vol. 6, No. 2.

Nelson R., Winter S. 1982 An Evolutionary Theory of Economic Change, Harvard University Press, Cambridge, MA.

Niedzielski P. 2003 Polityka innowacyjna w transporcie, Wydawnictwo Naukowe Uniwersytetu Szczecińskiego, Szczecin.

Niedzielski P., Łobacz K. 2011 Istota współczesnych innowacji: Specyfika, kierunki, trendy, [in:] Innowacje ustugowe, J. Perenc, J. Hołub (ed.), Warszawa.

Niedzielski P., Łobacz K. 2012 Diagnoza i analiza problemów komercjalizacji wiedzy $i$ transferu technologii na uczelni wyższej pod katem barier natury organizacyjnej, ekspertyza wykonana w ramach projektu "SCOUTING - aktywny system monitoringu i oceny potencjału rynkowego prac badawczych kluczem do współpracy nauki i przedsiębiorców", Szczecin-Łódź..

O’Shea R. P., Allen T. J., Chevalier A., Roche F. 2005 Entrepreneurial Orientation, Technology Transfer and Spin-off Performance of US Universities, "Research Policy", vol. 34, no. 7.

OECD 1997 Technology Incubators: Nurturing Small Firms, Organisation for Economic Co-Operation and Development, Paris.

OECD 2010 SMEs, Entrepreneurship and Innovation, OECD Publishing.

Ośrodki innowacji i przedsiębiorczości w Polsce. Raport 2010, 2010, K. B. Matusiak (ed.), PARP, Warszawa.

Phan P. H., Siegel D. S., Wright M. 2005 Science Parks and Incubators: Observations, Synthesis and Future Research, "Journal of Business Venturing”, Vol. 20, No. 2.

Pirnay E., Surlemont B., Nlemvo F. 2003 Toward a Typology of University Spin-offs, "Small Business Economics", No. 21.

Price C., Huston R., Meyers A. D. 2008 From the Classroom: A New Approach to Improve Technology Commercialization in University Medical Schools, "Journal of Commercial Biotechnology", vol. 14, No. 2, pp. 96-102.

Quinn R. E., Rohrbaugh J. 1983 A Spatial Model of Effectiveness Criteria: Towards a Competing $V$ alues Approach to Organizational Analysis, "Management Science”, Vol. 29, No. 3.

Ratinho T. 2011 Are they Helping? An Examination of Business Incubators' Impact on Tenant Firms, PhD dissertation, CPI Wöhrmann Print Service. 
Ratinho T., Henriques E. 2010 The Role of Science Parks and Business Incubators in Converging Countries: Evidence from Portugal, "Technovation", Vol. 30, No. 4.

Rekomendacje zmian w polskim systemie transferu technologii $i$ komergalizaci wiedsy, 2011, K. B. Matusiak, J. Guliński (ed.), PARP, Warszawa.

Romer P. 1986 Increasing Returns and Long-Run Growth, "Journal of Political Economy", Vol. 94, No. 5.

Rothaermel F. T., Thursby M. 2005 Incubator firm Failure or Graduation? The Role of University Linkages, "Research Policy", Vol. 34, No. 7, pp. 1076-1090.

Salman A., Majeed A.A. 2009 Sustainable Incubator Management - A Case Study for Pakistan. Part II, "The Pakistan Development Review”, Vol. 48, No. 4.

Schumpeter J. 1934 The Theory of Economic Development, Harvard University Press, Cambridge MA.

Sherman H., Chappell D. S. 1998 Methodological Challenges in Evaluating Business Incubator Outcomes, "Economic Development Quarterly", Vol. 12, No. 4.

Smilor R. W. 1987 Commercializing Technology through New Business Incubators, "Research Management", No. 30.

Stawasz E. 2006 Charakterystyka i potrzeby firm mysoko innowacyjnych z sektora MSP w regionie tódžkim, [in:] Konkurencyjność firm regionu tódzkiego na rynkach miedzynarodonych, L. Lewandowska [ed.], PTE, Oddział w Lodzi, Łódź.

Stawasz E. 2009 Realizacja i integracja polityki innowacyjnej i przedsiebiorczości (nybrane problemy na pryylktadzie Lodzৃ), [in:] Budowa zdolności innowacyjnych regionów, A. Nowakowska (ed.), Biblioteka, Łódź.

Stawasz E. 2011 Polityka innowacyjna wobec MSP, Zeszyty Naukowe Uniwersytetu Szczecińskiego No. 654, Ekonomiczne Problemy Usług No. 70, Szczecin.

Strategia liz̨ońska - droga do sukcesu rjednoczonej Europy. Edition I, 2002 Urząd Komitetu Integracji Europejskiej, Warszawa .

Trzmielak D. 2011 Problemy komergalizacji technologii w Polsce i na swiecie - analiza wynikón badan, Zeszyty Naukowe Uniwersytetu Szczecińskiego, No. 642, Ekonomiczne Problemu Usług, No. 70, Szczecin.

Unia Innowacji 2010 Komunikat Komisji do Parlamentu Europejskiego, Rady, Europejskiego Komitetu Ekonomiczno-Społecznego oraz Komitetu Regionów. Projekt przewodni strategii Europa 2020, Unia Innowacji, SEC (2010) 1161, Bruksela.

Wright M., Clarysse B., Mustar P., Locket A. 2007 Academic Entrepreneurship in Europe, Edward Elgar Publishing, Cheltenham (UK), Northampton (USA).

Yli-Renko H., Autio E., Sapienza H. J. 2001 Social Capital, Knowledge Acquisition, and Knowledge Exploitation in Young Technology-Based Firms, "Strategic Management Journal", Vol. 22, No. 6/7. 